\title{
Endless Summer (1964) - Consuming Waves and Surfing the Frontier
}

The Endless Summer defined our sport. For the first time the rest of the world would have a clear look at the surfing lifestyle.' Matt Warshaw, Surfer's Journal History of Surfing Films)

...Brown cobbled together $\$ 50,000$ and set out with two California surfers, Mike Hynson and Robert August, to produce a true documentary on real surfers. Not beach bums or playboys who sang to their girlfriends, surfers were athletes who enjoyed the adventure of scanning the globe in search of the perfect wave.' ('The Sick Six: Six of the Most Important Surf Movies Ever Made, from the Fifties to Now', http.yerbabuenaarts.org/himvideo/sicksix_pn.htm, accessed 1.08.00)

After World War II America and the West experienced a consumer boom resulting from greater disposable incomes, advances in technology and commodity production. Part of consumer culture at this time involved the pleasure derived from acquiring goods which came to symbolise lifestyles or identities (Featherstone 1991). The baby boom generation that followed the War became teenagers numbered ten to fifteen million in the 1950s with a potential spending power of nine billion dollars (Gillbert 1957:21). It is therefore unsurprising that this market became the target of advertising and mass media exploitation (Osgerby 2001). Teenagers, newly identified as potential markets for advertisers, were identified with enjoyment, freedom and came to symbolise the plenitude and benefits of modern capitalist culture (Gilbert 1986).

Part of the consumer boom for young people was in the growth of leisure activities; going to the movies, driving and sport. Surfing became inextricably linked with the growth in consumerism as it was identified as a hot new sport with a youthful focus, appealing to middle class, white youth and epitomising the ideal Californian lifestyle. A surf craze emerged in America and Australia comprising of surf music in the shape of The Beach Boys, Dick Dale and His Del-Tones, Jan and Dean.. The Beach Boys particularly were marketed as all-American high school boys who surfed, were clean cut, and cared only for cars, girls and fun, fun, fun. Hollywood produced up to seventy surf-related exploitation films purporting to lift the lid on just what happened on the beach when adults were not around to regulate undesirable behaviour. Out of this heady, consumerist mix of emerged what many surfers regard as the definitive surf movie, Bruce Brown's The Endless Summer (1964).

The Endless Summer has a simple premise, the quest for the perfect wave' which is one of the defining myths of surf culture and representations of surfing outside the subculture. Director and surfer, Bruce Brown followed two surfers, Robert August and Mike Hynson around the globe to experience an endless summer and catch the perfect wave. To do this the friends travelled to little known destinations such as Australia, New Zealand, South Africa, 
Tahiti and Ghana in addition to Malibu and Hawaii. Brown explained that: 'Originally we were just going to South Africa and then come back...But it turned out to be $\$ 50$ cheaper to go all the way round the world, so we did that. $^{2}$

The Endless Summer belongs to a sub-genre of surf films Booth (1996) describes as 'pure'. These are surf films made by surfers for a limited surfing audience and typically exhibited at surf clubs. Brown's credentials as a surfer, a surf filmmaker and his association with significant shapers such as Dale Velzy ensured the authenticity of his representaion of surf culture to its audiences. 'Pure' surf films relied on the film producer distributing and exhibiting them around a 'four wall' circuit. As with many four-wall producers at the time, Brown exhibited the film along with a running commentary around the usual high school halls, and club houses to enthusiastic surfer audiences. ${ }^{3}$ On the tour Brown developed a script from which he distilled the best of the jokes and script elements before recording a permanent soundtrack. In an effort to gain Hollywood studio distribution, Brown, aided by Paul Allen, toured around America to places such as Witchita, Kansas, a venue little famed for its waves, where the film ran for two weeks to full houses. However, something unexpected happened with The Endless Summer, it crossed over from niche to mainstream audiences when the distribution was taken up by Columbia. Indeed, such was the popularity of the film that Newsweek dubbed The Endless Summer one of the best 10 films of 1964.

So why was Endless Summer so popular? Robert August, one of the film's 'stars' believes that the re-release of the film in 1966 was a reminder to Americans of a more innocent time, providing them with time out from Vietnam and the possibility to have fun for a while, 'it was the right time for it' (Robert August, Surfer's Journal History of Surfing Films'). Bruce Brown is not sure:

I don't know...I've run into so many people who saw The Endless Summer particularly back east, and said it had some effect on them. But a lot of 'em, they didn't surf, and they never did surf. It's always been a mystery to me. ${ }^{4}$

A generation of surfers later, Thoms wrote of The Endless Summer:

What everyone picked up on was the beauty of surfing, the harmonious union of man and nature, the adventure implicit in riding waves no-one surfed before, and the sense of freedom to be found away from civilisation's complexity. ${ }^{5}$

Thoms, however, ignored the consumer aspect of The Endless Summer, conferring upon it an Edenic innocence with which it has been associated ever since. However, this chapter argues that it is impossible to wrest the film from its consumerist roots. The reasons for the popularity of The Endless Summer was that it perfectly expressed the dreams of American culture in a hedonist search for freedom from the restrictions of conformity in American culture from the early to mid sixties. Further, the main premise of the film, 
surfers' quest for the perfect wave, was attractive to American culture in this period, articulating a re-enactment of the conquering of the American frontier. As August suggests this might have reminded Americans of a simpler more innocent time before Vietnam.

\section{SURF EXPLOITATION AND THE TEENAGE CONSUMER}

In the early to mid 1950s, teenagers were represented as transgressive and the perceived problems of juvenile delinquency as a threat to the American way of life were, according to J. Edgar Hoover, second only to communism. ${ }^{6}$ However, the late fifties and early sixties saw the emergence of the "clean teen', a squeaky clean teeanger who was fun loving but conformed to the strictures of society. The clean teen phenomenon was, '.... quite literal product of the parent culture, fabricated from above, peddled down below... ${ }^{7}$ The rebellious teen icons such as Elvis, Jerry Lee Lewis and Chuck Berry were replaced by Pat Boone, Frankie Avalon and Annette Funicello. Clean teen stars were promoted across the media in films, pop music and television. Pat Boone starred in Bernadine(1957) and April Love (1957). He also successfully covered pop songs by black artists such as Fats Domino's 'Ain't That a Shame' in 1955. Fabian and Frankie Avalon starred in a number of surf related exploitation films such as Ride the Wild Surf (1966), Beach Party (1963) and Bikini Beach (1964). Just as pop music was 'tamed', so Hollywood quickly changed its representation of teenagers in the early sixties, depicting them as fun loving, clean living and most of all, good consumers. Surfing, previously regarded as transgressive, was caught up in the clean teen phenomenon when it was identified as a sport enjoyed by teenagers, but more importantly white, middle class teenagers. As surfing was also associated with California, the golden state, the attractions of surfing seemed overwhelming to the advertising and mass media industries.

The surf boom was fuelled by the release of a film in 1959 starring teen star, Sandra Dee as Gidget, the 'girl midget.' Gidget (1959) was adapted from Fred Kohner's book about his daughter Kathy's experiences with a bunch of surfers at The Point in Malibu. It starred Sandra Dee in the title role and heartthrob James Darren as surfbum wannabe, Moondoggie.
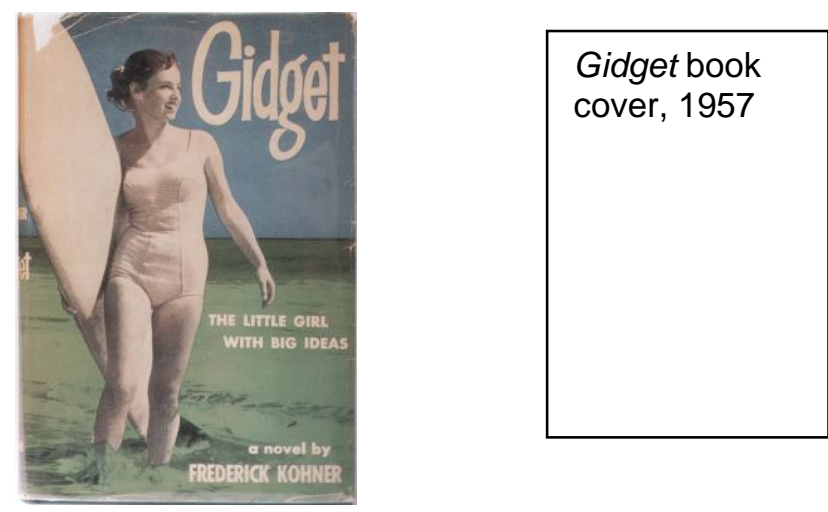

Gidget was a typical white, middle class teenager who had enough disposable income to either buy a surfboard, or cajole her doting parents to buy it for her. The story told of her romance with Moondoggie, and the romantic, dropout 
lifestyle of the surfbums lead by Kahuna. By the end of the film, Gidget got her man and converted Kahuna, previously a confirmed bachelor and layabout, into a productive member of society. Following on the success of Gidget, American Independent Pictures, released a series of seven exploitation films with a surfing background. The first of the series, Beach Party (1963) set the paradigm for the other films (Muscle Beach Party (1964), Bikini Beach (1964), Beach Blanket Bingo (1965), How to Stuff a Wild Bikini, Ghost in the Invisible Bikini).

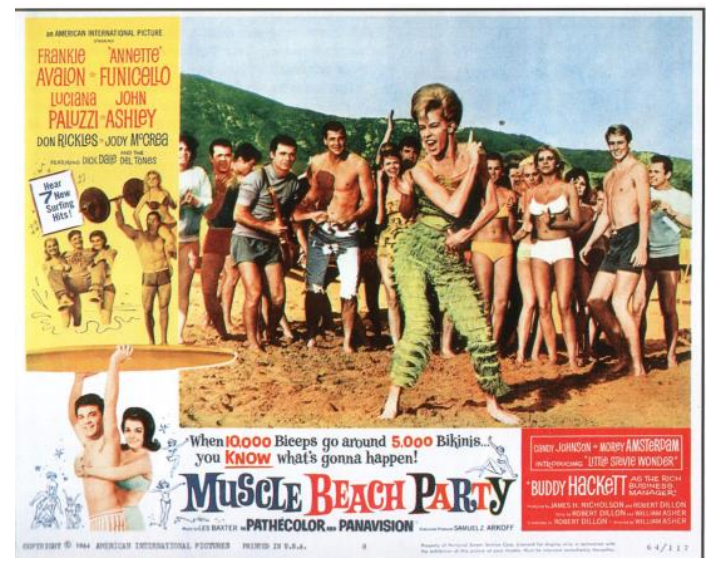

Poster Muscle Beach Party (1964) featuring Candy Johnson (Miss Perpetual Motion), Frankie Avalon and Annette Funicello are pictured bottom left.

Most of AIP's beach films starred teen idols, Frankie Avalon and Annette Funicello ${ }^{8}$ they included a regular gang of surfers such as Joel McCrae as Deadhead. There was also a regular supporting cast such as Harvey Lembeck as Eric von Zipper, a middle aged 'wild one' and Don Rickles in a variety of guises from Jack Fanny in Muscle Beach Party to Big Drop in Beach Blanket Bingo. The liminal nature of the beach, coupled with scanty beachwear and lack of adult supervision offered AIP the opportunity for frolics and sexual innuendo in the sand dunes, pop songs and slapstick comedy. However, this shamless exploitation of their culture caused such fury in the Californian surf community of the time that Mickey Dora, the most famous surfer in California and a vociferous opponent of surf commercialism, released a jar of moths onto the screen at Beach Party's first screening. Dora, however, was not above taking money for stunt work in the film. He also provided stunt footage for several other Hollywood films of the time such as Ride the Wild Surf (1964) and Gidget (1959).

Coincidentally around this time surfboard technology was also undergoing a revolution. Previously, surfboards were made from the increasingly rare and expensive balsa wood. This made them too expensive for the average teenager to buy. The weight of the surfboards also made them more difficult to carry and manoeuvre in the water. Surfboards were also scarce. A surfboard might take up to three weeks to craft. However, when Hobie Alter and Dale Velsay began to use foam, they could produce up to 160 boards per week at a cost of $\$ 70-\$ 80$ (Young,1994) Indeed Alter noted that 'If that movie'd [Gidgef] come out in the balsa era...no one could have supplied 'em.' 9 The production of cheaper and lighter boards enabled a whole generation of teenagers to take to the waves. When coupled with the growing affluence in California, an affluence which was especially experienced by 
teenagers, Malibu and other Californian surf spots soon became very popular and very crowded. The exploitation of the sport dismayed many of the bone fide surfers, and it was in an effort to depict an authentic surf lifestyle that Bruce Brown claims he produced The Endless Summer. The sobriety of the film is apparent from the press pack which is restrained, consisting of a brief history of surfing and some stills from the film with reviews from Time, The New Yorker and Playboy. When compared with the flashy, hyperbolic poster for Muscle Beach Party, the simplicity of The Endless Summer poster promises a mythic and idealised vision of surfing and surf culture as Robert August and Mike Hynson, '...follow this everlasting summer around the world.'

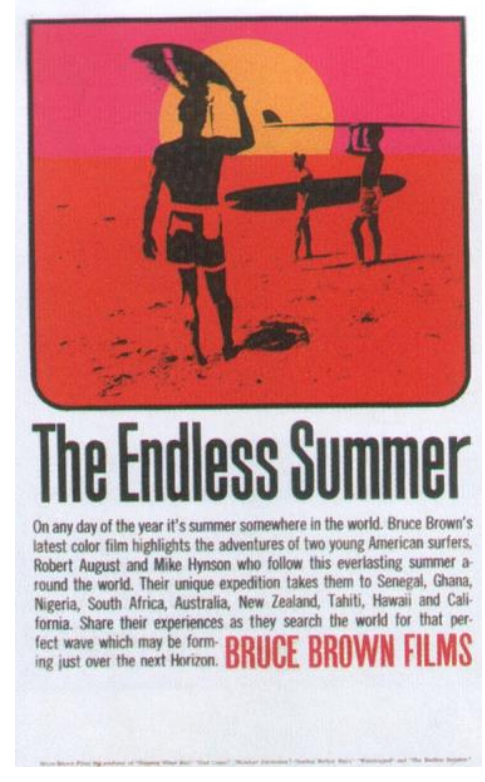

The Endless Summer (1964) poster image was taken from a photograph of Mike Hynson, Robert August and Bruce Brown.

Columbia, who took over the release of the film in 1966 deliberately placed a good deal of clear blue water between The Endless Summer as a quality product compared with its exploitative cousins ${ }^{1}$. Poster and advertising copy for The Endless Summer is predicated on youth and tourism. The notion of summer connotes the optimism of holidays and youth and adding 'endless' to this idea, holds out the promise that youth and holidays may go on forever. The poster copy begins: 'On any day of the year it's summer somewhere in the world.' It goes on to describe the quest for the perfect wave before concluding with the possibility for audiences to: 'Share their [Mike Hynson and Robert August's] experiences as they search the world for that perfect wave that might be forming just over the horizon.' The notion of the wave forming 'just over the horizon' is a promise of the fulfilment of the quest but also it holds an echo of pushing back a frontier or exploring a new and undiscovered country. This is a notion which Slotkin (1996) notes has concerned American culture since its origins ${ }^{10}$. Surfers' quest for the perfect wave then, emulates an underpinning value of American culture, an aim to extend the frontier of 'civilisation' and explore the wilderness ${ }^{11}$. It also intersects with the aim of the tourist to discover new locations in which the 'authentic' way of life of other peoples may be scrutinised. The surfer as constructed through tourist discourse is a phenomenon which originates from the dissemination of surfing from the Pacific Islands to America at the beginning of the twentieth century.

\footnotetext{
${ }^{1}$ Ironically, it was Columbia's film, Gidget which sparked the surf craze in 1959.
} 
Surfing was part of the ancient kapu caste system of Hawaii for at least one thousand years. When Captain Cook's ship, 'The Resolution' anchored at Kealano Bay the kapu system was already in decline. ${ }^{12}$ The arrival of European missionaries and disease hastened that decline, and surfing too virtually disappeared until the mid to late nineteenth century.

Surfing re-emerged as a result of consumerist discourse and modernity in the late nineteenth century. In an effort to overthrow plantation culture Hawaii developed its tourist potential using myths of paradise on earth and unspoiled beauty to attract mainly American tourists. ${ }^{13}$ The Waikiki Hotel in particular attracted tourists with its outrigger club and the Waikiki Beach Boys, native Hawaiians who gave surfing demonstrations to tourists. Two of these beach boys, Duke Kahanamoku and George Freeth are credited with the spread of surfing to America. Freeth gave surfing demonstrations at Redondo Beach in 1908 to advertise the new railway on the beach. Kahanmoku, an swimming Olympian champion spread the popularity of surfing through a mixture of demonstration and sponsorship of products such as Valspar Varnish ${ }^{14}$.

Prior to The Endless Summer surfers regularly made pilgrimages to 'the Islands'. There was a constant migration of surfers from the 1920s onwards to Hawaii to experience surfing's spiritual home. The Islands created an exotic mystique that conferred subcultural capital on the émigrés (Thornton: 1996). Indeed, one of the first surfing colonies in California at San Onofre celebrated the Hawaiian lifestyle in a hedonistic and bohemian lifestyle in the 1930s. This type of reverence for 'the Islands is translated into popular notions of surfing in the character of Kahuna in Gidget. Kahuna (who is named after a Hawaiian priest) is regarded as the head of the surfing colony at Malibu by reason of his lifestyle as a dropout but also because he has surfed the Islands ${ }^{15}$.

In The Endless Summer Bruce Brown takes the exotic mystique of surfing the 'other' and develops it into a global quest for the perfect wave. However, despite its simple premise, the discourses constructing the nature of this perfect wave and representations of surfers and other places in the film could only be expressed in such a fashion as a consequence of American culture in that specific historic and societal moment. Indeed, consumerism which underpins exploitation films in that era is also as crucial to the production of The Endless Summer than Columbia or Bruce Brown would care to admit. Discourses, such as consumerism and youth construct notions of surfers and surfing in America at this time. It is also these discourses which encouraged the production of exploitation films, surf music and the exploitation of the sport. How this new sport is appropriated by capitalism in order to promote specific values is discussed in relation to discourses concerning leisure, holidaymaking and the construction of the exotic 'other'. These ideas intersect with America's perception of itself as a young nation. Surfing expresses themes of these intersecting discourses reflecting perceptions of American youthfulness, vigour, playfulness and the myth of the frontier. 


\section{America: Consuming Youth and the Exotic Other.}

Before discussing discourses of youth and consumerism it is worth pausing to reflect upon discourses constructing America in the late 50s, early 60s. This part of the discussion will touch upon surfing briefly and these points will be developed in the section on surfing in California in the early 60s. The reasons for discussing discourses constructing America in this era are twofold. First, The Endless Summer uses particular images to represent youth and these images are constructed in American culture of the time. Since the late fifties California, home of the typical American surfer, was regarded as a state of golden people who were all young, tanned and affluent ${ }^{16}$. Second, America was 'discovered'17 in 1492 as a result of European exploration and expansion. However, America was imagined prior to Columbus on maps as 'Terra Incognita' and assumptions were made by Europeans about the inhabitants of such a land. These imaginings were influenced by notions of the Medieval Wild Man ${ }^{18}$, America was imagined to be the location of the Garden of Eden, populated by innocent, childlike and untainted peoples. Once Europeans began to colonise America European clerics and academics began to position the indigenous population as children. The continent was positioned as 'the New World' as opposed to Europe, the Old World. These associations informed representations of America from the $16^{\text {th }}$ century to the present and continue to influence contemporary culture in notions of America as a youthful society. These notions also influenced America's ideas about its own culture and is particularly prevalent in America's worship of youth and youthfulness.

Gans (1988) suggests that much of American ideology rests upon the notion of personal liberty, and the personal freedom of choice. Within American capitalism there is the notion that an individual can make money by striving harder than anyone else. This competitiveness is a major component of the American Dream which suggests that it is every person's duty to strive and ultimately win. These ideas are enshrined in what Slotkin describes as America's frontier myth in which early settlers conquer the land, pushing back the frontier and civilising the wilderness. By the early 60 s there were no more frontiers to conquer except space and the ocean. Surfers seemed to represent the frontiersmen conquering the final frontier to America. Indeed in 1958 the Saturday Evening Post noted that surfers represented: '... the last frontier. Civilisation drops behind them when they leave the shore and the beauty and challenge of the great oceans is all around them.' ${ }^{19}$ Surfers seemed to symbolize the Californian spirit. They were golden people presented golden possibilities and golden youthfulness.

The early sixties was an optimistic time for California before civil unrest became an issue and Vietnam was but a cloud on the horizon. Although there was a Cold War, America experienced an unprecedented boom in affluence and this was centred in perceptions of California where jobs in the aircraft industry offered the lure of riches and wealth in addition to a comfortable lifestyle. Further, California was regarded as a youthful state, having a large younger population as a result of the unprecedented move of families in the 1940s to California. The ownership of pools in California accounted for $40 \%$ of all pools owned in America in $1959 .{ }^{20}$ Indeed, by the 
late 1950s, early 1960s, California seemed to offer the concrete reality of the all American Dream in which anything was possible so long as an individual worked hard. America's attraction to California was consolidated in a survey by Look magazine in 1960 which revealed that $11 \%$ of Americans would choose to live there. ${ }^{21}$ As May also notes the car and the transport infrastructure of California were integral to the state's psyche. In the late 1960 s approximately $66 \%$ of the land in South California's urban landscape was implicated in car ownership either as roads, parking lots or service stations. Indeed, car culture along with surfing are the two most popular Californian youth leisure activities celebrated in the early music of the Beach Boys. These benefits were extolled in the Beach Boys lyrics which described car culture (Fun, Fun, Fun, Surfing Safari), girls (California Girls) and surfing (Surfin' USA). Indeed the latter seemed almost to connote surfing as America. An issue of Cosmopolitan in 1957 described California as a 'teenage paradise': '...[where] "mountains, beaches and play-conscious cities add up to a teen-age pleasureland." (May 1999:34) Teenagers in California were positioned as the most healthy and conforming teenagers in America ${ }^{22}$. Travel and surfing as noted above are inexorably linked as noted above, and these two activities coalesced in the notion of the surfing safari (the 'surfari' which is discussed below). It was the young, white, middle classes who took surfing to heart at the end of the 1950s and into the 60s. The heart of surf culture was located in Malibu, California. The location was of crucial importance to the technological advances (the aircraft industry as noted above) and also the commodification of the sport.

\section{Commodification of Surfing in California}

The technological advances of the aircraft industry in California in this period also made possible the growth in surf culture. Hobie Alter is credited with the first exploitation of foam technology in surfboard production. Alter's aim was to shape a board which could substitute for rare and expensive balsa wood. Coincidentally, the foam board offered the opportunity to produce boards quicker and which were lighter than any previous boards. This meant better manoeuvrability on the wave, quicker and cheaper production. Foam technology was quickly adopted by Alter's main rival Dale Velzy at Venice Beach. Velzy aimed '...to make boards as easy to surf as I could. Instead of taking two years to learn to surf, with the chips [potato chip boards] it would take four weeks. ${ }^{23}$ Velzy was so successful he was able to buy himself a Mercedes. His altruism was legendary amongst Californian surfing, he would give good surfers free surfboards, send surfers to international contests in Australia, he also gave Bruce Brown his first camera and enough money to shoot his first film, Slippery When Wet (1958). However, films were not the only advance in the development of surf culture. In the early sixties, the first major magazine, The Surfer, appeared which would cement the international surfing community and promote Californian surf culture.

The Surfer started in 1961 as a 10,000 copy newsletter promoting film maker John Severson's latest surf film, Surf Happy. The newsletter sold 5000 copies in South California. This inspired Severson to produce the newsletter as a quarterly magazine, The Surfer in 1961. Within three months it sold 5000 
copies and became a crucial component of surf culture. Initially The Surfer promoted a Californian notion of the fantasy surfing lifestyle with psychedelic covers, articles about travel and high quality surfing photography. Early editions included articles on surfing ideals. In 1965, Wardy, for instance, claimed that 'Surfing is a release from exploding tensions of $20^{\text {th }}$-century living, escape from the hustling, bustling city world of steel and concrete, a return to nature's reality. ${ }^{24}$ This articulated the romance of the leisure surfer's escape to the natural which was to become fully developed with the emergence of the soul surfer of the 1970s. Wardy too expressed the surfer's: '...endless search for the windless day, an uncrowded beach, the perfect wave.' reiterating disenchantment with crowded beaches. The Surfer which became known as 'the surfer's bible' presented surfers with images of perfect waves every two months in the early 1960s. In an early editorial, 'Surfing Is...' Severson described The Surfer as: '....a dream magazine. I saw that right away. The perfect surf, the faraway places...we all dream about the same things. ${ }^{25}$ This notion of the daydream is worth discussing here as it is central to consumer and tourist discourse and, ultimately in surfing, the perfect wave.

\section{FANTASY, DAYDREAMING AND THE ROMANTIC TOURIST}

By the early 1960s, as discussed above, Malibu waves had become too crowded. Indeed, once a hot new surf spot was discovered word quickly travelled and it became a nightmare to surf. Warshaw notes that in the '50s and early '60s surf magazines and films were quite transparent about the best locations for waves. However:

Discovery....invited ruin. In the late 1950s, when the "perfect wave" designation floated above Malibu like a neon sign, surfers were banging off one another in the lineup like heated molecules. To varying degrees, the same would eventually hold true for the Pipeline, Kirra, Jeffreys,

Grajagan, and any other spot renowned and cursed as "perfect." For many surfers...the real search for the perfect wave has been less to do with adventure, romance, and the pursuit of new experiences and more with just getting the hell away from what...Mickey Dora called "all the surf dopes, ego heroes, rah-rah boys, concessionaires, lifeguards, fags, and finks." Surfers on the road didn't look for anything particularly different. They wanted Malibu (or Kirra, or Grajagan, etc) without the crowds. ${ }^{26}$

Indeed, such was the pressure on popular surf spots that Surfer stopped identifying locations in the mid sixties. In the late fifties onwards, Californian surfers began to travel further afield on the surfari to find the perfect wave. The surfari was celebrated in songs by the Beach Boys such as Surfin' USA and Surfin' Safari, the former listed popular surf spots throughout the world. However, as Warshaw notes above, the aim of the surfari was not to discover new waves, rather it was to rediscover waves which surfers already knew. Thus, according to Warshaw, films such as The Endless Summer and magazines such as Surfer promote travel to 
distant beaches as a dream, a fantasy, 'reality heightened by imagination'. ${ }^{27}$ This aspect of travel and consumerism is important to address before discussing The Endless Summer.

Leisure and tourism is located within consumer culture and it is the ways that material goods are used that gives cultural meaning. Goods, '....act as meaningful makers of social relations; indeed, part of their usefulness is that they are full of meaning. It is in acquiring and exchanging things that individuals come to have social lives.' 28 Goods are imbued with meaning through social rituals such as collecting, cleaning, giving gifts. Specific objects acquire special meaning within groups of people. Jon Stratton (1985), for instance, suggests that surfing and biking, based upon commodities, tend to use objects in a symbolic manner. In bikie culture, clothing, and behaviour is predicated around the motor bike. Reckless driving, for instance, is valued above caution and bikers who die in an accident are regarded as heroes by the culture. Hierarchies develop within biker groups through the expression of these values. Similarly surf culture, which also values risk taking, organises itself around totemic objects such as the surfboard or the perfect wave ${ }^{29}$. However, it is not only acquiring material goods that gives meaning in culture, it is in imagining the acquisition.

Surfing, as suggested above, is a leisure activity predicated on consumerism. It is the romantic aspect of consumerism that is crucial here, for as Colin Campbell argues that consumerism is based upon desire and the possibility of achieving the perfect life through buying and consuming objects or experiences $^{30}$. This separates the physical from the imaginary world for the consumer who: '. . learns to substitute imaginary for real stimuli and by selfconsciously creating and manipulating illusions or imaginary experiences or emotions in daydreams and fantasies constructs his or her own pleasurable environment.'31 Images are an important part in this daydream of the perfect life. However, these images can never live up to the dream.

The holiday also conjures up an image of the perfect experience whether in reality or in the images constantly broadcast on television, the Internet or printed in newspapers, magazines and travel brochures. These alluring images also encourage the daydream of the potential tourist and fantasy:

Names like Waikiki, Nice, Majorca, Acapulko, Bali and Marrakech roll across the page evoking images of sun, pleasure and escape. In a world dominated by bureaucracies and machines, we are offered these destinations as retreats to a childlike world in which the sun always shines, and we can gratify all our desires. ${ }^{32}$

This quotation neatly summarises many of the discourses which construct a notion of the holiday. First, there is the idea that the holiday is a retreat or escape from the routine of everyday life. Next there is the notion of a return to childishness and the implicit notion of a return to an Edenic state of innocence, in which tourists can satisfy their merest whims. These ideas, at 
their root, coalesce around notions of time and the ways in which time is segmented in modern Western cultures, but the cultural appropriation of space is also significant in an examination of tourism. As Turner and Ash argue, tourism is implicated geographically in the 'pleasure periphery', in which certain geographical locations are designated tourist areas by virtue of their proximity to urban centres. Tourist destinations tend to be approximately 2-4 hours away from big cities of the northern or industrialised zone. For America the pleasure periphery is listed as the Caribbean, Latin America (Mexico, Tijuana, Acalpulco) and the Pacific Islands. As discussed above, Hawaii was a popular destination for rich American tourists from the mid $19^{\text {th }}$ century. It appealed to notions of the exotic, Paradise and the simple life. Although Turner and Ash wrote in the mid 70s their arguments concerning holidaymaking remain valid and are peculiarly appropriate to the present discussion as they were almost contemporary.

Mass tourism is a phenomenon arising from a number of diverse factors including modernity and globalization which occurred in European and Western culture from the $17^{\text {th }}$ century to the present. The drive towards measurement of time and space in the Renaissance and Enlightenment had two distinct outcomes in the late $18^{\text {th }}$ and early $19^{\text {th }}$ century. First, the measurement of space in maps from the $15^{\text {th }}$ century onwards meant that space was dislocated from place and became an abstract concept.

Boundaries which were symbolic demarcations of space as they divided nations on paper encouraged the development of nationalisms. The symbolic of the national boundary became concrete reality between 1750-1875 when national identities and the incorporation of non-European countries into Europe took place. ${ }^{33}$ The accumulation of goods and peoples of other nations into Europe enabled Europeans to gain a sense of their own national identities by comparing or defining themselves against other peoples. Usually this comparison relied upon the juxtaposition of European nations with the negative and exotic 'Other' peoples of South America, North America, Africa, etc. The compilation of maps also meant that travellers no longer feared the unknown when setting out on a journey. Coupled with the invention of navigational tools so that a ship knew in which direction it would encounter land the globe increasingly seemed a safer place. By the mid $19^{\text {th }}$ century with improved roads and the introduction of railways, space and time increasingly shrank.

Time was also segmented with the invention of the mechanical clock. In rural societies time was measured by the seasons - in the spring, summer and autumn the land was worked, in the winter it lay fallow. However, the invention of the mechanical clock changed this as it divided time up into discreet fragments where one either worked or did not work. The demarcation of leisure (non working) and work time was further developed in the climate of the capitalist and industrialised cultures of the West. The concept of work/leisure in the $19^{\text {th }}$ century Industrial Revolution was underpinned by the values of the middle class Protestant work ethic. ${ }^{34}$ and also Romanticism. Work was considered worthy and merited payment. Conversely leisure was the opposite of work, as it was a voluntary activity and 
linked with play. The holiday as open to everyone rather than just upper and middle classes developed throughout the nineteenth century. The concept of leisure was born and with it the romantic belief that happiness may be achieved by the pursuit of well-deserved pleasure. For instance, the holiday is often predicated as a time in which one may refresh oneself physically, mentally and spiritually. This enables the individual to return to work replenished. Holiday time is constructed as liminal time in which one may shed the trappings of 'normal' identity and indulge in playful activities which the individual would not do at home from over drinking and eating, to sightseeing or even casual sex. The notion of play enables a childish escapist attitude to the holiday experience, '...holidays attach a permission to adults to regress to the terrific anticipatoriness of childhood and its passion to be free of all these encumbering, impervious, unignorable others. ${ }^{35}$

A further interrelated reason for the desire to retreat to an idealised lifestyle is a result of urbanisation. Urry (1990) notes the growth of urbanisation with its attendant overcrowding and the squalor of city life from the late $18^{\text {th }}$ century induced in city dwellers a wish for escape to a rural idyll. Coupled with Romantic sensibilities, this developed a desire within city dwellers to return to a rural or idyllic space, a space which may be likened to Eden or Arcadia; in short, a paradise on earth. To this end tourists may anticipate the holiday or daydream about it using tourist literature as a means to imagine what it might be like. This 'imagining' of future pleasures is a symptom of modern hedonism:

...pleasure is sought via emotional and not merely sensory stimulation, whilst...the images which fulfil this function are either imaginatively created or modified by the individual for self-consumption, there being little reliance upon the presence of 'real' stimuli. These two facets mean that modern hedonism tends to be covert and self-illusory; that is to say, individuals employ their imagination and creative powers to construct mental images which they consume for the intrinsic pleasure they provide, a practice best described as day-dreaming or fantasizing. ${ }^{36}$

Day-dreaming, an integral part of the sojourn ${ }^{37}$ or tourist experience, is predicated upon the visual and may be experienced in holiday brochures, television programmes or other mass media texts. Rosengren takes the notion of visuality further in his discussion of the sojourn, 'to dwell in a place temporarily or as a stranger, the implication being that once returned to the point of departure the sojourn is of no further consequence. '38. The 'surfari' is a type of sojourn, an activity based upon sensation but contains many elements of tourism such as the daydream (which Rosengren describes as the 'self-departure'). The experience of sojourning is fuelled by the rhetoric and images in surf magazines and films which hold out the promise for escape from the everyday routine. Indeed, in The Endless Summer August and Hynson continuously indulge in daydreams evoking the surf of the familiar in California and Hawaii. However, unlike the daydreaming of tourism surfing is not a purely visual experience. It is also about sensation. Surfers are 
inspired by the promise of the 'flow' or the 'stoke' in addition to visual aspects of the experience, 'The bigger the wave, the bigger the challenge, you blend for a moment with immense power. You feel close to God.'39 Surfing however, articulates concerns of contemporary tourists who crave the 'bombardment of the senses' beyond purely visual sensations. ${ }^{40}$

Rojek and Urry liken the contemporary tourist to the $19^{\text {th }}$ century flâneur who strolls through the labyrinthine city and who probes through the superficial shell of the city in order to reveal its sensual pleasures. The flâneur is a phenomenon of modernity as he ${ }^{41}$ performs identity. His identity is spectacular, performing and performative at the same time in a way similar to the tourist. Surfing may not take place in the city, however, it could be argued that the surfer enacts and performs his/her identity and experiences the ocean through sensation, the flow of the surf. Like the city, the ocean too has its dangers, such as the possibility of 'being eaten' or experiencing a wipeout on the wave.

Finally, in a discussion of holidays and surfing, it is important to dwell, briefly on notions of the beach which was quickly identified as an ideal destination by tourist companies in the nineteenth century. The contemplation of nature in solitude and the sublime attracted the Romantics to the seashore and a number of themes of the beach arose from this. The first was the sexualization of the beach. Percy Bysshe Shelley, for instance, likened swimming to 'orgasmic sensations' and Valery, the French poet described swimming as 'fornication with the wave'42. The sea was also regarded as the nurturer of life. Novalis, a German Romantic, compared the sea with a mother or womb. Lenček also notes that the growth of romantic literature in the early $19^{\text {th }}$ century in which delicate heroines suffering from consumption were preyed upon by bounders who seduced and left them:

...these literary accounts linked physical deterioration with moral turpitude, and implicated the beach, with its shifting borders and transitional figures, as the cause of the patient's sudden loss of ethical orientation. Thus, by degrees, the beach acquired in the popular mind the typically doubled and oxymoronic meaning of the pharmacon, a drug that can both heal and kill. ${ }^{43}$

Thus, the beach is constructed as a part of a number of clashing discursive formations including healer and destroyer of spirit and life, heaven or hell on earth, health giving but with the possibility for moral degradation.

\section{THE ENDLESS SUMMER: CONSTRUCTING THE KNOWN/UNKNOWN}

The Endless Summer falls into the documentary mode, although as discussed below, it does not always represent a true picture of what happened on Mike Hynson, Robert August and Bruce Brown's quest for the perfect wave. The film glosses over some of the more tedious aspects of production. Each location is represented as containing certain elements. Robert August admits, 
'We went to a lot of places there was just nothing.' ${ }^{44}$ Nevertheless this aspect of production is not apparent in the film's narrative.

The pressbook for the film quotes several reviews which praise the film, Playboy for instance notes:

The Endless Summer is one of the most pleasant and least self-conscious travelogs and sports commentaries to come along in years, a delightful sojourn into surfdom. ${ }^{45}$

The opening titles pick up the theme of the title in gold-drenched images of surfboards packed into a car driving towards the sun. Travel is highlighted in the opening credits, a yacht bobs on sun-flecked water and an airplane flies towards the sun.

The film begins in California, Brown contextualizes surf culture describing the favoured type of surf: 'Most surfers like to ride a regular board and perform on a medium sized wave.' When Brown suggests the surfer 'performs' he refers to the popularity of the hotdogging style of surfing. Hotdogging was a performance style of surfing in which the surfer performed manoeuvres on the board. The ideal hotdogger wave was the small to medium Malibu wave. Matt Warshaw reinforces the argument that surfers enact both a spectacular and performative identity when he describes hotdogging as, 'trick riding.... often on beaches full of onlookers'. ${ }^{46}$ Brown lists hot surfers of the early 1960s such as Mickey Dora, who at that time was the star of the Malibu medium wave, Phil Edwards, the first to surf the Pipeline, Hawaii whom Brown had starred in his previous film, Surfing Hollow Days (1962) ${ }^{47}$ and Australian, Nat Young, who had just won the World Surfing Championship in San Diego. There is the archetypal wipeout ${ }^{48}$ and footage of surfing in Hawaii with a list of the most famous waves, the Garbage Hole, Waikiki and Number 3. Brown describes the object of surfing, '...to remain in the curl, stay as close to the wave without getting caught by it. All the movements in surfing, stalling, turning, riding the nose are directed towards the ultimate aim of riding the curl.' There is some slapstick of surfers, carrying their surfboards, attempting to cross the busy highway, a sequence which demonstrates the overcrowding of the Californian surf.

Another negative aspect of Californian surfing, according to Brown, is the winter:

The ultimate thing for all of us would be to have an endless summer; the warm water and waves without the summer crowds of California. The only way to do this is to follow the summer season as it moves around the word.

To achieve this goal Robert August and Mike Hynson sit in front of a fire one evening planning such a trip. They consult travel books such as National Geographic, read a malaria manual, a book on how to repel shark attacks, and daydream about their forthcoming surfari. The following ninety minutes shows the pair visiting Senegal, Ghana, South Africa, Australia, Tahiti and 
Hawaii. Each location is stereotyped in a particular way. Brown notes that in Senegal they stamp 'sucker' on your forehead as they are forced to stay in a government hotel costing them $\$ 30$ per day and $\$ 1$ for coffee. Brown estimates that each wave costs $\$ 9.95$. However, they convert several natives (a term used incessantly by Brown) to surfing.

In Accra they stay in a small fishing village, the first white men ever seen by some of the villagers. Brown stresses the unchanging way of life for thousands of years. Here villagers make canoes from a single tree trunk, money is rarely used and when Hynson and August surf the children quickly make paddleboards for themselves and begin surfing. The surf is compared favourably with that of Malibu. The lack of surfers is stressed in South Africa - where there are only one hundred surfers around the Cape. However, the brotherhood of surfing is stressed when all one hundred arrive on the beach to welcome Robert and Mike. Despite the lack of surfers, when Mike and Robert hitchhike outside Durban ('you can wait three days for a car') they manage to hitch a lift with two passing surfers. In South Africa, defying narrative conventions for the achievement of the goal towards the film's resolution, Robert and Mike discover the perfect wave, just off Cape St Francis, described by Brown in typical hyperbole as, 'so perfect it could be made by a machine...so long I couldn't get most of them [the waves] on one piece of film.' The local fishermen note the waves in this area are funny looking things, 'like pipes' and, as Brown asserts, they are like this three hundred days a year. The water temperature here is also perfect at seventy degrees with a prevailing offshore wind. This wave is so long and perfect that the surfers get cramps in their legs from squatting down in the curl. Brown concludes, 'I couldn't help but think of the hundreds of years these waves must've been breaking here but until this day no one had ever ridden one. Thousands of waves must've gone to waste right now on Cape St. Francis.' Hyperbole continues in the Australian segment in which Brown, August and Hynson cannot discover any waves and are constantly told, 'You should have been here last winter'. However, the perfection of New Zealand waves echoes that of South Africa when on Christmas Day they surf in a cove by themselves ('I can't even show you a full ride it would take the whole second half of the film.')

The final leg of the journey marries the weird with the familiar. In Tahiti where there are reputedly no waves the surfers discover well formed waves. In Papeete waves can be ridden in and out. The film climaxes in Hawaii ('good old Hawaii) the spiritual home of surfers. Brown demonstrates the art of the filmmaker by strapping the camera to the front of the board to show the waves from a surfer's point of view. There are shots of the Pipeline which is described as 'a Roman gladiator's pit' because of the razor-sharp coral underneath the shallow wave. The spikes can wound or kill, 'Any wipeout at the Pipeline in Hawaii is a bad one.' As if to underline this point a surfer, Bob Pike, takes a wipeout and Brown reports he sustains a broken collar-bone and three broken ribs. The board of another surfer, Butch van Arsdale is broken in two - and, as Brown informs the audience, surfboards are so tough they cannot be broken even if you drive a car over them ${ }^{49}$. The films ends with Brown's admonition, 'With enough time and money you could spend the rest 
of your life following the summer around the world.' This describes the wish of many surfers, to have enough free time and money to surf without the routine of work and everyday living. The film gives surfers a taste of what such a life might be like. The cultural context and discourses constructing surfing in this era are discussed above. The final part of this article discusses the influences of consumerism, leisure and youth culture on the construction of the film, and makes a tentative conclusion for the film's continuing popularity.

\section{THE ENDLESS SUMMER: SURFING THE FRONTIER, SELLING THE WAVE}

It is suggested earlier in this essay that The Endless Summer is a documentary. It is worth reiterating that surfing films are not documentaries in the traditional sense of the mode. That is, they are not sober and objective narratives but, certainly in the early 1960s, are produced to be exhibited in front of a live, enthusiastic audience. Brown would play music from a tape recorder whilst narrating to the audience from his written script. The film therefore is meant to 'stoke' the audience. It is also imperative that something is happening throughout the film, there can be no quiet passages. Therefore, there are disruptions in the narrative in reel and real time. So, for instance, while Mike and Robert fly from Africa to Australia Brown injects interest by showing footage of Hawaii, 'While Mike and Robert are on their way to Australia, let's look at waves in Hawaii.' When they 'arrive' in Australia he directs the audience to rejoin Robert and Mike. This is obviously a narrative device to prevent boredom in the audience, but also uses up excess footage of Hawaii. However, these flashbacks also serve the purpose to remind surfers of the familiar, compared with the unfamiliar. Pleasure in the past is reflected upon and compared with the imperfection of the present. Therefore, when Hynson and August attempt to hitch a lift in Durban, rather than showing several minutes of the isolated African road, Brown takes the audience to Newport Beach, California, 'the dirty old Wedge'. The stress is on the crowded beach and waves and this is compared with the isolation and strangeness of the road. Similarly, when there is a lull in the waves at Bell's Beach in Perth, Australia Rod Sumpter describes a surfing session with Nat Young in the winter. In Sydney August and Hynson reflect upon the monster waves in Waimea which need 'big gun' surfboards to ride them. In these three flashbacks there is a juxtaposition of the familiar and unfamiliar, but there is also an engagement in daydreaming and imagination which is an integral part of modern hedonism. In all of these cases pleasure and the perfection of the imagination, the daydream, is compared with the imperfection of reality.

Flashbacks are one of the contrivances of the narrative. Brown takes liberties with the reality of the journey. For instance, he describes how the perfect wave was discovered after a trek across three miles of sand dunes at Cape St Francis in South Africa. Narrative tension is built up when Brown comments that the odds of finding a perfect wave are ten million to one. As he says this, the film shows the surfers on top of a sand dune looking down on the ocean, 'They finally got their first look at St Francis, South Africa.' The camera then 
shows the perfect wave. Brown builds up tension and the 'stoke' in the audience by selling them the wave in South Africa, a wave so perfect it looks like it was made by a machine, so long it cannot be contained on one film, 'I timed them in the curl for forty-five seconds.' He exhorts the surfers to visit South Africa by reminding them of the wasted opportunities to ride this perfect wave, 'Out of a whole days surfing...each wave was perfect.' Indeed, Brown compares this wave with Malibu and Rincorn and concludes it is better, '....and it's better every day.' The wave is a commodity to be sold to surfer audiences and it is the commodification of the wave which it is now useful to discuss. The Endless Summer shares many of its values with the image of 'clean teens'. The two stars of the film, Robert August and Mike Hynson are typical of middle class, clean cut youth. At the airport they dress in suits, their hair is neatly cut and they are respectful to their elders - in a scene in Africa, they call the village chief 'sir'. They are, at the same time, ambassadors of American youth and frontiersmen venturing into the wilderness and colonising waves in undiscovered territories. Further, as noted above, their exploration of the unknown wave is only made possible by increasingly cheap airfares in the early sixties.

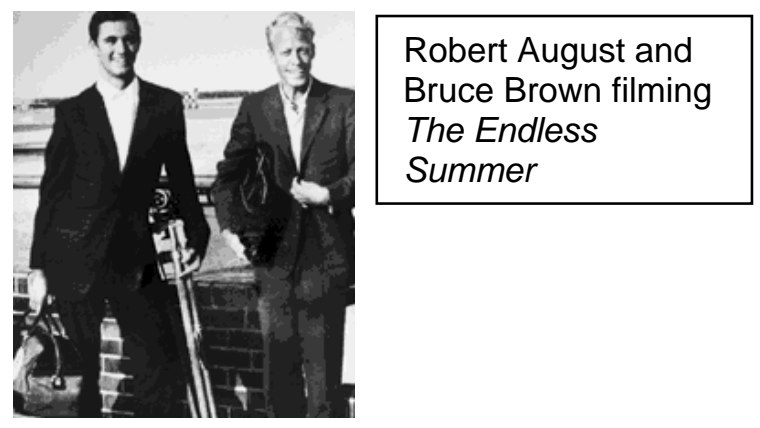

Surfing at this time was regarded as a leisure sport and associated with the holiday. The holidaymaker or tourist would attempt to discover the authentic or the untouched that elusive Eden or paradise which was the antithesis of everyday routine. The notion of discovering the untouched society intersected with the myth of the American frontier; the notion that Americans reclaimed the wilderness for civilisation just as their ancestors did from the earliest days of the American frontier ${ }^{50}$.

The predominant themes in the film conglomerate around known/unknown, named/unnamed, exotic/familiar and crowds/isolation. The latter, as noted above, is the theme on which the film is predicated, Brown begins the film with an account of the crowds on the beaches of Malibu and Hawaii. The theme of the crowd is juxtaposed with that of the isolation and the notion of the idyllic ride in locations around the world. For instance, on Christmas Day August and Hynson surf by themselves in New Zealand on what is an extremely long wave, 'I can't even show you a full ride. It would take the whole second half of the film.' Brown notes that eventually the ride becomes so long that August and Hynson resort to talking with each other as a means of diversion from the boredom. Obviously this is an exaggeration however, what Brown appears to be doing here is selling the unknown wave. Similarly, in Durban, South Africa, whilst waiting for a lift Brown notes that you can wait for three days before seeing a car. This is, 'one of the few places in the world you can be alone on 
a main highway.' This is juxtaposed with footage of crowds on the beach at 'the dirty old Wedge' in California. Later when August and Hynson find a beach and go surfing in South Africa, Brown states, '... most beaches haven't been set foot on for ten years'.

The notion of the crowded and the isolated is intimately linked with that of the exotic/familiar (America). The exotic is located as a negative against the familiar of California or Hawaii. California is the physical home of surfing, whereas Hawaii (described as 'good old Hawaii' by Brown) is the spiritual home. The film begins with the familiar waves of California and then travels to Hawaii. These two locations are continuously compared with unknown and exotic locations throughout the film in the form of flashbacks. August and Hynson travel to Hawaii on the last leg of their journey (there, '....wasn't a much better place to be than Hawaii'), in effect, travelling from the familiar to the familiar. Brown concludes, 'Hawaii is truly a land of an endless summer.'

Throughout the film there is reference to distance related back to California in either time or miles. For instance, in Dakata, Senegal, Brown states, 'Here they were only four hours away off an airplane from the United States and already into better surf than the day they left California.' Time and space has been conflated. 'They rode those waves knowing they were the first to ever do it and also knowing the closest surfer to them was four thousand miles away.' August and Hynson are portrayed in this segment of the film as civilising influences, akin to the civilising influence on America by Europe after Columbus. They descend like gods into the primitive village in Ghana - so primitive they have no money, rather society is predicated upon barter and exchange. They are the first white men ever seen by many of the villagers, and as the missionaries in Hawaii, they set about spreading the good word, in this case, surfing. They establish a surf school to teach the children how to surf. The children quickly take to this new pastime, making paddleboards for themselves to surf the waves ${ }^{51}$. Adults too enjoy surfing, and one attempts to surf in his outrigger canoe in a style similar to that of early surfing in the Pacific Islands.

The wilderness, uncultivated and unshaped is evoked in descriptions of the unknown surf spot. A wave with ideal conditions in Durban, South Africa, described as 70 degrees with an offshore wind, '...doesn't even have a name'. In Dakata, Senegal, Brown describes;'....surf that no one had ever ridden before, and as far as we know, surf that no one ever knew before.' These unnamed surf spots are given names by Brown, names which in some cases remain to this day. In Tahiti, for instance a wave considered so unknown is named 'The Other Spot', a title that is as obscure as the location. It is worth noting that the names may overlay names given to these places by local people in a manner similar to that of Columbus when he claims and names islands for the Spanish throne. In other words, this echoes a colonial enterprise as it claims symbolic ownership of the wilderness for surfing and America.

Another aspect of the known/unknown binary is related to the representation of surfers encountered by August and Hynson. So when the duo visit South 
Africa, all the local surfers, numbering one hundred and some from as far away as four hundred miles, descend upon the beach and surf with them. In this narrative Brown suggests surfers are part of a global tribe, sharing the waves and a special brotherhood. However, the difference between different surf cultures is also noted, South African surfers tend to be older than Californian surfers. Australian surfers are of similar age, but a very competitive with the 'Yanks' - a phenomenon which becomes significant within two years of the making of The Endless Summer with the advent of the shortboard revolution ${ }^{52}$.

The quest for this perfect wave did not aim to discover an unknown wave, rather it aimed to recreate the known. The constant comparison between waves in Lagos, Senegal, Cape St Francis, etc with California and Hawaii is a search to discover a new Waimea or Malibu. Just as surfers the world over are similar but different to Californian surfers, so the waves are also continuously compared to those already known waves in California and Hawaii. In Sydney, the lack of waves and flat conditions are juxtaposed with the mountainous waves of Waimea in Hawaii which were first ridden in 1958 after surfers spent ten years looking at the waves. These waves need special surfboards, 'big guns' and are surfed by, 'only a handful of surfers ride sportsmen and nuts'. In these dangerous waves the flailing surfboard can cut you in half. For this reason in a wipeout sufers dive away from boards. The water temperature is also compared with 'home', in South Africa it is 54 degrees, whilst Lagos's ninety-one degrees is so warm, 'it melted the wax right of the surfboards.' What is of note here, however, is that up to 1958 this wave had not been ridden or even given a name. It is when it is named and tamed that surfers, usually American surfers, claim the wave as theirs.

Unknown waves, however, can be dangerous and Brown constantly stresses the importance of surfing with a friend in strange waters. It is not only the waves that are dangerous but what lurks beneath them. In Australia and South Africa beaches are cordoned off from shark attack. In Australia, sharks, rather ominously, are known as 'the men in grey. In South Africa when the sinister grey fins are seen cutting the surface of the water when Hynson and August are surfing Brown warns that despite netting, there is a fifty/fifty chance you will be killed by a shark. However, the danger is mitigated when the sharks are identified as porpoises. Brown turns this into a political statement, noting that porpoises and sharks do not swim in the same waters, 'they have yet to integrate.' In addition to sharks in Lagos there is the hazard of the stone fish, 'If you step on a stone fish you die in about fifteen minutes.'

In the global quest for the perfect wave, Brown, August and Hynson make known the unknown and so incorporate locations and waves into the American culture. It is a culture based upon consumerism. A quest for the perfect wave could not have been made by any other society or subcultural surfing group than American, specifically Californian, at this time. All the conditions for such a journey were in place within this specific time and cultural moment. In addition to being a journey of exploration and adventure, it was a journey of colonisation and incorporation of other surfers and waves 
into American surf culture. It affirmed America's dominance of global surfing at the time and may be crucial to the popularity of the film with surfing and non-surfing audiences.

2 'The Sick Six: Six of the Most Important Surf Movies Ever Made, from the Fifties to Now', http.yerbabuenaarts.org/himvideo/sicksix_pn.htm, accessed 1.08.00.

3 Keith Beattie, "Sick, Filthy, and Delirious: surf film and video and the documentary mode." Continuum: Journal of Media \& Cultural Studies 15, no. 3, (2001):pp. 333-348.

${ }^{4}$ Bruce Brown quoted in Drew Kampion, Stoked.The History of Surf Culture (Köln: Evergreen, 1998), 109.

${ }^{5}$ Albie Thoms, "Morning of the Earth," Tracks, February 1972 republished in his Polemics for a New Cinema (1978), Sydney: Wild and Woolley, 125.

6 Thomas Doherty Teenagers and Teenpics: The Juvenilization of American Movies in the 1950s. (London, Boston (Mass): Unwin Hyman 1988).

7 Thomas Doherty Teenagers and Teenpics: The Juvenilization of American Movies in the 1950s. (London, Boston (Mass): Unwin Hyman 1988) 221.

${ }^{8}$ Except The Ghost in the Invisible Bikini which starred Nancy Sinatra. Sometimes, as in How to Stuff a Wild Bikini or in the spin off Ski Party, work commitments meant that Funicello or Avalon made guest appearances, usually providing a 'punchline' to the plot.

${ }^{9}$ Drew Kampion, Stoked: The History of Surf Culture (Köln: Evergreen, 1998) 69.

${ }^{10}$ Richard Slotkin The fatal environment : the myth of the frontier in the age of industrialization, 1800-1890 (Scranton, Pa., Middletown, Conn.: Wesleyan University Press, 1986).

${ }^{11}$ Joan Ormrod, “Just the lemon next to the pie'...Apocalypse, History and the Limits of Myth in Big Wednesday (1978)" (Scope: An Online Journal of Film Studies February, 2005).

12 In their paper, "Holua: Myth or Reality?", for the North American Society for Sport History, Proceedings and Newsletter (1989), Reet A. Howell and Maxwell L. Howell assert that the view that missionaries hastened the decline of the kapua caste system is ill founded. Rather, ancient Hawaiian sports such as Holua (sled sliding), maika (bowling) and heenalu (surfing) declined as a result of the destruction of the kapua system in 1819 by King Liholiho.

${ }^{13}$ Bryan H. Farrell Hawaii the Legend that Sells (Honolulu: The University Press of Hawaii, 1982) 15.

${ }^{14}$ The advert was published in The Saturday Evening Post, 1922 and the copy describes Kahanamoku as 'famous athlete, expert on the surf-board and champion 100-metre swimmer'. Kahanamoku is reported as commenting, 'No matter how long the board is used in the water, the Valspar is not affected...' Nancy Schiffer Surfing (Atglen, 1998) 122.

${ }^{15}$ R. L. Rutsky "Surfing the Other: Ideology on the Beach," Film Quarterly 52, no. 4 (1999).

16 Kirse Granat May "Suburban Eden: Californian Youth Images in Popular Culture 19551966." PhD diss., University of Utah, 1999.

${ }^{17}$ I place 'discovered' in quotation marks as at the time of Columbus' arrival in the islands off the American coast there were 6 million inhabitants living in the continent.

${ }^{18}$ Hayden White Tropics of Discourse: Essays in Cultural Criticism (London, Baltimore: John Hopkins University Press, 1978) and Stephen Greenblatt Marvelous Posessions: The Wonder of the New World, The Clarendon lectures and the Carpenter lectures (Oxford; Clarendon, 1991).

${ }^{19}$ Kirse Granat May "Suburban Eden: Californian Youth Images in Popular Culture 19551966." (PhD diss., University of Utah, 1999)137.

${ }^{20}$ Kirse Granat May "Suburban Eden: Californian Youth Images in Popular Culture 1955-

1966." (PhD diss., University of Utah, 1999) 27.

${ }^{21}$ Kirse Granat May "Suburban Eden: Californian Youth Images in Popular Culture 19551966." (PhD diss., University of Utah, 1999) 19.

22 Thomas Doherty Teenagers and Teenpics: The Juvenilization of American Movies in the 1950s. (London, Boston (Mass): Unwin Hyman 1988)

${ }^{23}$ Drew Kampion Stoked. A History of Surf Culture (Koln: Evergreen, 1998) 57.

${ }^{24}$ Wardy cited in Sam George The Perfect Day: 40 Years of Surfer Magazine (San Francisco: Chronicle Books LLC, 2001) 15.

${ }^{25}$ Matt Warshaw Surfriders: In Search of the Perfect Wave (Del Mat, California: Tehabi Books, 1997) 38. 
${ }^{26}$ Ibid., 38.

27 Ibid., 43.

${ }^{28}$ Celia Lury Consumer Culture (Oxford: Polity, 2001) 12.

29 Jon Stratton, "On the Importance of Subcultural Origins." In The Subcultures Reader, edited by Ken Kelder and Sarah Thornton, 181-190, London and New York: Routledge, 1997.

${ }^{30}$ Colin Campbell The Romantic Ethic and the Spirit of Modern Consumerism (Oxford: Basil Blackwell, 1987).

${ }^{31}$ Celia Lury, Consumer Culture (Oxford: Polity, 1996) 73.

${ }^{32}$ Louis Turner and John Ash, The golden hordes : international tourism and the pleasure periphery (London: Constable, 1975) 11.

${ }^{33}$ Malcolm Waters, Globalization Key Ideas (London: Routledge, 2001).

${ }^{34}$ Max Weber, The Protestant Work Ethic and the Spirit of Capitalism (London: Allen and Unwin, 1930).

${ }^{35}$ Fred Inglis The delicious history of the holiday (London: Routledge, 2000) 9.

${ }^{36}$ Colin Campbell The Romantic Ethic and the Spirit of Modern Consumerism (Oxford: Basil Blackwell, 1987) 77.

${ }^{37}$ William R. Rosengren "The Rhetoric of Sojourning," Journal of Popular Culture 5 no. 2 (1971): 298-314.

38 Ibid. 298.

39 Klapp, cited in Rosengren, 1971:301.

${ }^{40}$ Chris Rojek and John Urry. "Transformations of Travel and Theory." In Touring Cultures: Transformations of Travel and Theory, edited by Chris Rojek and John Urry, 1-22. London, New York: Routledge, 1997.

${ }^{41}$ In this discussion, 'he' is possibly more appropriate than 'she' as surfing in The Endless Summer and the era under discussion, tends to be masculine orientated. For more information on the long and illustrious history of women surfers, refer to Andrea Gabbard's Girl in the Curl: A Century of Women in Surfing (Seattle: Seal Press, 2000).

42 Lena Lenček and Gideon Bosker The beach: the history of paradise on earth (London: Pimlico, 1999) 106.

${ }^{43}$ Lena Lenček, and Gideon Bosker The beach: the history of paradise on earth (London: Pimlico, 1999) 111.

${ }^{44}$ The Surfer's Journal 50 Years of Surfing on Film : Brown/MacGillivray/Greenough, VHS. The Surfer's Journal, 1996).

${ }^{45}$ Playboy review from The Endless Summer cited from the pressbook for The Endless Summer.

${ }^{46}$ Matt Warshaw The Encyclopedia of Surfing (Orlando, Austin, New York, San Diego, Toronto, London: Harcourt Inc., 2003) 276.

${ }^{47}$ The Pipeline is a legendary break in Hawaii that surfers watched but did not surf. However, within two hours of Edwards first ride fifteen surfers were riding the wave. Bruce Brown commented, 'In one day it went from nobody surfed there to a 'spot'.'

${ }^{48} \mathrm{~A}$ surfer experiences wipeout when they fall off their board and are engulfed by the wave. The wipeout was a typical narrative device of 'pure' surf films and was originated in early films made by surfers such as Bud Browne.

${ }^{49}$ Elements such as the Roman gladiator's pit, hyperbole in oral storytelling are an integral part of John Milius' Big Wednesday (1978) which contains many elements of The Endless Summer. Perhaps one of the reasons it is held in such high esteem by surfers.

${ }^{50}$ Richard Slotkin The fatal environment : the myth of the frontier in the age of industrialization, 1800-1890 (Scranton, Pa., Middletown, Conn.: Wesleyan University Press, 1986).

51 Indeed these paddleboards bear a strong resemblance to those made and surfed by Tahitians and recorded in German anthropological films from the early twentieth century. One wonders how the children picked up the notion of a curved board tip, were they told by August, Brown and Hynson, or did they have previous knowledge of this component of the paddleboard?

52 The shortboard revolution occurred in the mid sixties when surfing values changed from medium waves to tubes. Australian and American surfers enacted a war on the waves through the surf press in which, most infamously, Australian John Witzig infuriated American surfers by suggesting 'We're Tops Now' in Surfer volume 8, number 1. 'Californian surfing is so tied and stifled by restrictions that are its own creation' (John Witzig 'We're tops now' 
Quoted in Sam George The Perfect Day: 40 Years of Surfer Magazine (San Francisco: Chronicle Books, 2001) 24. 